\title{
How to appraise qualitative research
}

\section{Calvin Moorley, ${ }^{1}$ Xabi Cathala ${ }^{2}$}

10.1136/ebnurs-2018-103044

${ }^{1}$ Nursing Research and Diversity in Care, School of Health and Social Care, London South Bank University, London, UK

${ }^{2}$ Institute of Vocational Learning, School of Health and Social Care, London South Bank University, London, UK

\section{Correspondence to:}

\section{Dr Calvin Moorley, Nursing}

Research and Diversity in Care, School of Health and Social Care, London South Bank University, London SE1 OAA, UK; Moorleyc@ Isbu.ac.uk

\section{Introduction}

In order to make a decision about implementing evidence into practice, nurses need to be able to critically appraise research. Nurses also have a professional responsibility to maintain up-to-date practice. ${ }^{1}$ This paper provides a guide on how to critically appraise a qualitative research paper.

\section{What is qualitative research?}

Qualitative research concentrates on understanding phenomena and may focus on meanings, perceptions, concepts, thoughts, experiences or feelings. ${ }^{2}$ Qualitative research examines how or why a phenomenon occurs. It collects data in the form of words, texts and or images via interviews, observations, photographs or document reviews. Qualitative research does not use discrete variables like those used in quantitative approaches. In critically appraising qualitative research, steps need to be taken to ensure its rigour, credibility and trustworthiness (table 1).

Some of the qualitative approaches used in nursing research include grounded theory, phenomenology, ethnography, case study (can lend itself to mixed methods) and narrative analysis. The data collection methods used in qualitative research include in depth interviews, focus groups, observations and stories in the form of diaries or other documents. ${ }^{3}$

\section{Authenticity}

\section{Title, keywords, authors and abstract}

In a previous paper, we discussed how the title, keywords, authors' positions and affiliations and abstract can influence the authenticity and readability of quantitative research papers, ${ }^{4}$ the same applies to qualitative research. However, other areas such as the purpose of the study and the research question, theoretical and conceptual frameworks, sampling and methodology also need consideration when appraising a qualitative paper.

\section{Problem}

Purpose and question

The topic under investigation in the study should be guided by a clear research question or a statement of the problem or purpose. An example of a statement can be seen in table 2. Unlike most quantitative studies, qualitative research does not seek to test a hypothesis. The research statement should be specific to the problem and should be reflected in the design. This will inform the reader of what will be studied and justify the purpose of the study. ${ }^{5}$

\section{Literature}

An appropriate literature review should have been conducted and summarised in the paper. It should be linked to the subject, using peer-reviewed primary research which is up to date. We suggest papers with a age limit of 5-8 years excluding original work. The liter- ature review should give the reader a balanced view on what has been written on the subject. It is worth noting that for some qualitative approaches some literature reviews are conducted after the data collection to minimise bias, for example, in grounded theory studies. In phenomenological studies, the review sometimes occurs after the data analysis. If this is the case, the author(s) should make this clear.

\section{Theoretical and conceptual frameworks}

Most authors use the terms theoretical and conceptual frameworks interchangeably. Usually, a theoretical framework is used when research is underpinned by one theory that aims to help predict, explain and understand the topic investigated. A theoretical framework is the blueprint that can hold or scaffold a study's theory. Conceptual frameworks are based on concepts from various theories and findings which help to guide the research. ${ }^{6}$ It is the researcher's understanding of how different variables are connected in the study, for example, the literature review and research question. Theoretical and conceptual frameworks connect the researcher to existing knowledge and these are used in a study to help to explain and understand what is being investigated. A framework is the design or map for a study. When you are appraising a qualitative paper, you should be able to see how the framework helped with (1) providing a rationale and (2) the development of research questions or statements. ${ }^{7}$ You should be able to identify how the framework, research question, purpose and literature review all complement each other.

\section{Sampling}

There remains an ongoing debate in relation to what an appropriate sample size should be for a qualitative study. We hold the view that qualitative research does not seek to power and a sample size can be as small as one (eg, a single case study) or any number above one (a grounded theory study) providing that it is appropriate and answers the research problem. Shorten and Moorley ${ }^{8}$ explain that three main types of sampling exist in qualitative research: (1) convenience (2) judgement or (3) theoretical. In the paper, the sample size should be stated and a rationale for how it was decided should be clear.

\section{Methodology}

Qualitative research encompasses a variety of methods and designs. Based on the chosen method or design, the findings may be reported in a variety of different formats. Table 3 provides the main qualitative approaches used in nursing with a short description.

\section{Procedure}

The authors should make it clear why they are using a qualitative methodology and the chosen theoretical approach or framework. The paper should provide details 


\begin{tabular}{|c|c|}
\hline Term & Description \\
\hline Credibility & $\begin{array}{l}\text { Credibility is establishing the study's } \\
\text { findings with reality. This demonstrates } \\
\text { the believability or truth of the findings. } \\
\text { It ascertains whether the study findings } \\
\text { are believable based on the participants' } \\
\text { original data and participants' views. }\end{array}$ \\
\hline Confirmability & $\begin{array}{l}\text { Confirmability questions how the } \\
\text { study findings are supported by the } \\
\text { data. It identifies any bias that may } \\
\text { have been present. It is the level to } \\
\text { which the findings can be confirmed } \\
\text { or corroborated. Confirmability is } \\
\text { concerned with determining that data } \\
\text { and interpretations of the findings are not } \\
\text { made up by the researcher's imagination, } \\
\text { but clearly derived from the data. }\end{array}$ \\
\hline $\begin{array}{l}\text { Member } \\
\text { checking }\end{array}$ & $\begin{array}{l}\text { This is a technique in which the data, } \\
\text { interpretations, analytical categories } \\
\text { and conclusions are fed back to the } \\
\text { participants from whom the data were } \\
\text { collected. This process strengthens the } \\
\text { data as it allows participants to clarify } \\
\text { and correct any errors and provide } \\
\text { additional information if necessary. It } \\
\text { can also highlight how participants and } \\
\text { researchers view the data differently. }\end{array}$ \\
\hline Rigour & $\begin{array}{l}\text { This is the systematic approach and } \\
\text { techniques used to ensure reliability and } \\
\text { validity of the study. }\end{array}$ \\
\hline Reflexivity & $\begin{array}{l}\text { Reflexivity is the practice of critical } \\
\text { self-reflection about oneself as a } \\
\text { researcher. It involves looking at one's } \\
\text { biases, preferences and preconceptions. } \\
\text { The researcher should reflect on their } \\
\text { relationship to the participant, and how } \\
\text { the relationship affects participant's } \\
\text { answers to questions or decisions in the } \\
\text { research. For example, how does being a } \\
\text { nurse impact on interviewing a patient in } \\
\text { your care? }\end{array}$ \\
\hline Triangulation & $\begin{array}{l}\text { Triangulation refers to the use of different } \\
\text { ways of collecting or analysing data and } \\
\text { the cross-checking of these to see if } \\
\text { findings from different methods, different } \\
\text { analysts, different theories or different } \\
\text { reliability checks of sources show similar } \\
\text { results. }\end{array}$ \\
\hline Trustworthiness & $\begin{array}{l}\text { Trustworthiness is concerned with how } \\
\text { the researchers establish the study } \\
\text { findings as credible, transferable and } \\
\text { confirmable. }\end{array}$ \\
\hline Transferability & $\begin{array}{l}\text { This refers to the level of which the study } \\
\text { findings can be transferred to other } \\
\text { situations. The reader should look at the } \\
\text { detail of the study including the methods } \\
\text { and rigour applied and compare this to } \\
\text { their own situation to determine if the } \\
\text { findings can be applied to their own } \\
\text { situation. }\end{array}$ \\
\hline
\end{tabular}

of participant inclusion and exclusion criteria as well as recruitment sites where the sample was drawn from, for example, urban, rural, hospital inpatient or community. Methods of data collection should be identified and be appropriate for the research statement/question.
Table 2 Example of research question and problem statement

\begin{tabular}{ll}
\hline $\begin{array}{l}\text { Research } \\
\text { question }\end{array}$ & $\begin{array}{l}\text { How do patients' experience postoperative } \\
\text { pain control management? }\end{array}$ \\
\hline $\begin{array}{l}\text { Statement of } \\
\text { problem/aim }\end{array}$ & $\begin{array}{l}\text { To explore patients' experience of } \\
\text { postoperative pain control }\end{array}$ \\
\hline
\end{tabular}

\section{Data collection}

Overall there should be a clear trail of data collection. The paper should explain when and how the study was advertised, participants were recruited and consented. it should also state when and where the data collection took place. Data collection methods include interviews, this can be structured or unstructured and in depth one to one or group. ${ }^{9}$ Group interviews are often referred to as focus group interviews these are often voice recorded and transcribed verbatim. It should be clear if these were conducted face to face, telephone or any other type of media used. Table 3 includes some data collection methods. Other collection methods not included in table 3 examples are observation, diaries, video recording, photographs, documents or objects (artefacts). The schedule of questions for interview or the protocol for non-interview data collection should be provided, available or discussed in the paper. Some authors may use the term 'recruitment ended once data saturation was reached. This simply mean that the researchers were not gaining any new information at subsequent interviews, so they stopped data collection.

The data collection section should include details of the ethical approval gained to carry out the study. For example, the strategies used to gain participants' consent to take part in the study. The authors should make clear if any ethical issues arose and how these were resolved or managed.

\begin{tabular}{|c|c|}
\hline $\begin{array}{l}\text { Type of qualitative } \\
\text { approach }\end{array}$ & Description \\
\hline Ethnography & $\begin{array}{l}\text { Researches the behaviour, interaction, } \\
\text { perception and link between people, } \\
\text { groups and community. Often has } \\
\text { an anthropological component and } \\
\text { focuses on context or culture. Data } \\
\text { usually collected using interviews or } \\
\text { observations. }\end{array}$ \\
\hline Grounded theory & $\begin{array}{l}\text { Data systematically collected usually } \\
\text { through interviews. The researcher } \\
\text { identifies, refines and integrates } \\
\text { categories to produce a theory or modify } \\
\text { existing theory. }\end{array}$ \\
\hline Phenomenology & $\begin{array}{l}\text { Researches people's experiences or } \\
\text { meaning of a phenomenon. Data usually } \\
\text { collected using interviews. }\end{array}$ \\
\hline Case study & $\begin{array}{l}\text { Researches individuals, events, } \\
\text { organisations or an entity. Data } \\
\text { collected using observations, reports, } \\
\text { documents or interviews. }\end{array}$ \\
\hline Narrative analysis & $\begin{array}{l}\text { Researches individuals' lives. Data } \\
\text { collected as stories and often in first } \\
\text { person account of the experience. }\end{array}$ \\
\hline
\end{tabular}




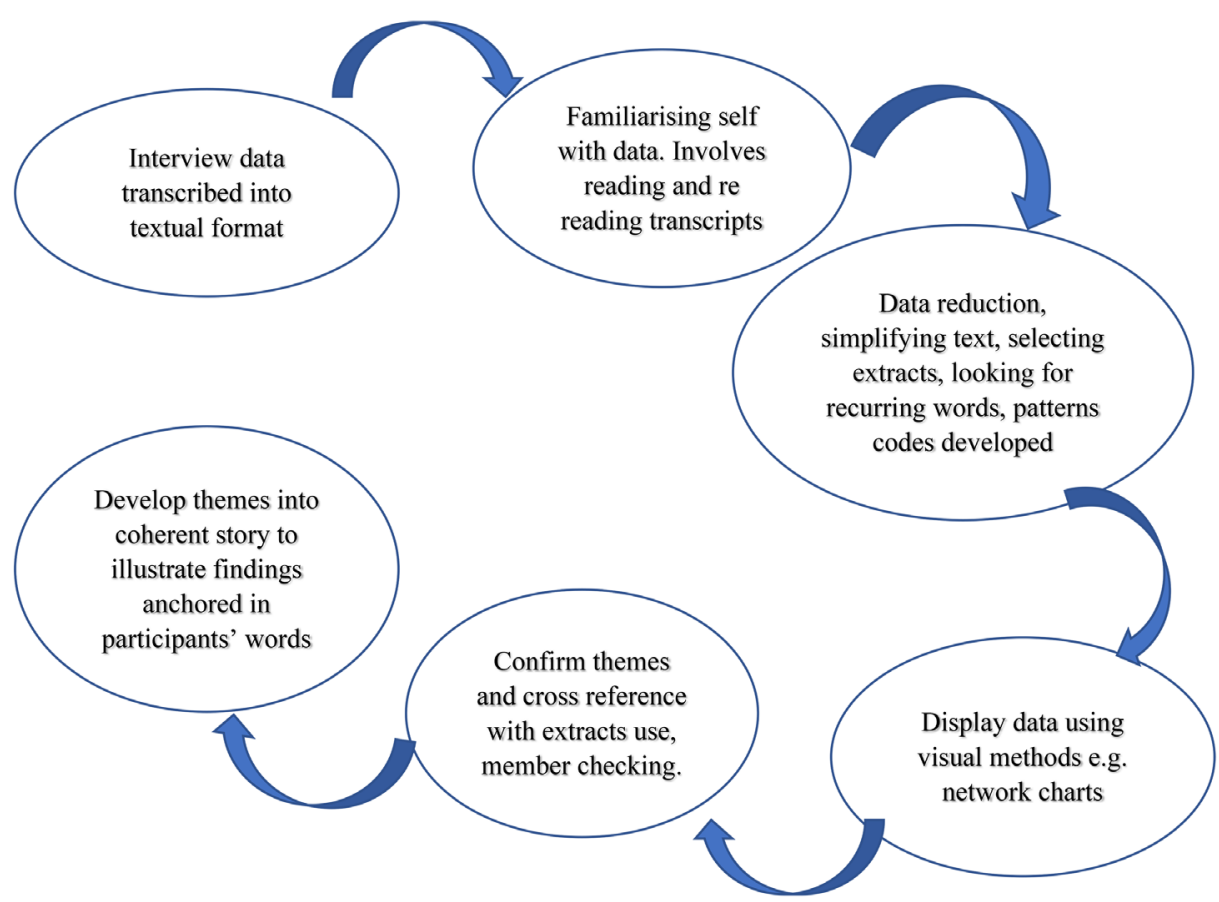

Figure 1 Example of data analysis diagram.

\section{Analysis}

The approach to data analysis (see ref ${ }^{10}$ ) needs to be clearly articulated, for example, was there more than one person responsible for analysing the data? How were any discrepancies in findings resolved? An audit trail of how the data were analysed including its management should be documented. If member checking was used this should also be reported. This level of transparency

\begin{tabular}{|c|c|c|}
\hline $\begin{array}{l}\text { Critiquing sub } \\
\text { headings }\end{array}$ & Areas to consider & Notes \\
\hline Credibility & $\begin{array}{l}\text { Authors' credentials: are they experts in the area? } \\
\text { What are the authors' qualifications and affiliations? } \\
\text { Are the research study findings linked with the data collected? } \\
\text { Is there sufficient information provided on how the research was conducted? } \\
\text { Are the study findings believable? }\end{array}$ & \\
\hline Setting & Does the setting reflect the context of the research and its applicability? & \\
\hline Confirmability & $\begin{array}{l}\text { Did the researchers discuss or refer to the documentation, or paper trail, of their decisions, and } \\
\text { methods related to the research? } \\
\text { Can you identify from the research that field notes or memos were used? } \\
\text { Can you identify the researcher's decision-making through a reflexive journal or diary? }\end{array}$ & \\
\hline $\begin{array}{l}\text { Ethical approval } \\
\text { and practice }\end{array}$ & $\begin{array}{l}\text { Is there confirmation of ethical approval? } \\
\text { Can you identify good ethical practice, for example, consent, confidentiality, no harm or risk to } \\
\text { participants or how these were minimised? } \\
\text { Are the relevant ethical issues identified and strategies to address these put in place? }\end{array}$ & \\
\hline Data collection & $\begin{array}{l}\text { Is there a clear account of how the data were collected? } \\
\text { Did the researchers make clear the participant recruitment process? } \\
\text { Is the data collection method justified? }\end{array}$ & \\
\hline $\begin{array}{l}\text { Patterns and } \\
\text { theme formation }\end{array}$ & $\begin{array}{l}\text { Have the researchers discussed how the patterns and themes have emerged? } \\
\text { Can you identify the data analysis process? }\end{array}$ & \\
\hline Rigour & $\begin{array}{l}\text { Have the researchers discussed how or if they used triangulation in the study? (not all } \\
\text { researchers use triangulation) } \\
\text { Have the researchers discussed member checking and if more than one researcher performed the } \\
\text { analysis? }\end{array}$ & \\
\hline Transferability & $\begin{array}{l}\text { Have the authors made clear the applicability of their findings to similar areas of practice? } \\
\text { Are the implications for practice discussed? } \\
\text { in social science areas? } \\
\text { Do the findings inform practice? }\end{array}$ & \\
\hline
\end{tabular}


contributes to the trustworthiness and credibility of qualitative research. Some researchers provide a diagram of how they approached data analysis to demonstrate the rigour applied (figure 1).

\section{Validity and rigour}

The study's validity is reliant on the statement of the question/problem, theoretical/conceptual framework, design, method, sample and data analysis. When critiquing qualitative research, these elements will help you to determine the study's reliability. Noble and Smith ${ }^{11}$ explain that validity is the integrity of data methods applied and that findings should accurately reflect the data. Rigour should acknowledge the researcher's role and involvement as well as any biases. Essentially it should focus on truth value, consistency and neutrality and applicability. ${ }^{11}$ The authors should discuss if they used triangulation (see table 2) to develop the best possible understanding of the phenomena.

\section{Findings}

Themes and interpretations and implications for practice In qualitative research no hypothesis is tested, therefore, there is no specific result. Instead, qualitative findings are often reported in themes based on the data analysed. The findings should be clearly linked to, and reflect, the data. This contributes to the soundness of the research. ${ }^{11}$ The researchers should make it clear how they arrived at the interpretations of the findings. The theoretical or conceptual framework used should be discussed aiding the rigour of the study. The implications of the findings need to be made clear and where appropriate their applicability or transferability should be identified. ${ }^{12}$

\section{Discussions, recommendations and conclusions}

The discussion should relate to the research findings as the authors seek to make connections with the literature reviewed earlier in the paper to contextualise their work. A strong discussion will connect the research aims and objectives to the findings and will be supported with literature if possible. A paper that seeks to influence nursing practice will have a recommendations section for clinical practice and research. A good conclusion will focus on the findings and discussion of the phenomena investigated.
Qualitative research has much to offer nursing and healthcare, in terms of understanding patients' experience of illness, treatment and recovery, it can also help to understand better areas of healthcare practice. However, it must be done with rigour and this paper provides some guidance for appraising such research. To help you critique a qualitative research paper some guidance is provided in table 4 .

\section{Competing interests None declared.}

Patient consent for publication Not required.

Provenance and peer review Commissioned; internally peer reviewed.

๑ Author(s) (or their employer(s)) 2019. No commercial re-use. See rights and permissions. Published by BMJ.

\section{References}

1 Nursing and Midwifery Council. The code: Standard of conduct, performance and ethics for nurses and midwives. 2015 https://www.nmc.org.uk/globalassets/sitedocuments/nmcpublications/nmc-code.pdf (accessed 21 Aug 18).

2 Seers K. Qualitative data analysis. Evid Based Nurs 2012;15:2.

3 Barrett D, Twycross A. Data collection in qualitative research. Evid Based Nurs 2018;21:63-4.

4 Cathala X, Moorley C. How to appraise quantitative research. Evid Based Nurs 2018;21:99-101.

5 Lewis S. Qualitative inquiry and research design: choosing among five approaches. Health Promot Pract 2015;16:473-5.

6 Parahoo K. Nursing research: Principles, process and issues. 3 edn. Hampshire: Macmillan Publishers Limited, 2014.

7 Fulton S, B K-M. Gathering and appraising the literature. In: LoBiondo-Wood G, Haber J, eds. Nursing Research: Methods and Critical Appraisal for Evidence-Based Practice. 7 edn. St Louis MO: Mosby Elsevier, 2010.

8 Shorten A, Moorley C. Selecting the sample. Evid Based Nurs 2014;17:32-3.

9 Kendall L. The conduct of qualitative interviews: Research questions, methodological issues, and researching online. Handbook of research on new literacies: Routledge, 2014:151-68.

10 Thorne S. Data analysis in qualitative research. Evid Based Nurs 2000;3:68-70.

11 Noble H, Smith J. Issues of validity and reliability in qualitative research. Evid Based Nurs 2015;18:34-5.

12 Gadoud A, Taylor P, Hussain JA. How to appraise a qualitative study. Br J Hosp Med 2013;74:271-4. 